\title{
KNOWLEDGE ENTREPRENEURSHIP CONTRIBUTION AND SELF EFFICACY TO IMPROVE CREATIVITY STUDENT
}

\author{
Kurjono \\ Email: kurjono@upi.edu
}

\begin{abstract}
Abstrak
Permasalahan klasik dalam dunia pendidikan yang masih aktual adalah pengangguran yang bersumber pada rendahnya kreativitas lulusan. Tujuan penelitian ini adalah untuk mengetahui dan mengkaji pengaruh dari pengetahuan kewirausahaan dan self efficacy terhadap kreativitas mahasiswa. Penelitian ini dilakukan pada mahasiswa UPI Bandung.

Desain penelitian ini termasuk dalam penelitian ex-post facto, yakni model penelitian yang kejadiannya sudah terjadi sebelum penelitian dilaksanakan. Penelitian ex-post facto hanya mengungkap gejala-gejala yang ada dan telah terjadi sebelumnya, sehingga dalam penelitian ini tidak perlu memberikan perlakuan terhadap variabel dalam penelitian. Penelitian ini merupakan penelitian kuantitatif diukur dengan menggunakan metode survey explanatory. Analisis data dibantu dengan aplikasi SPSS versi 21. Hasil penelitian menunjukan pengetahuan kewirausahaan dalam kondisi tinggi, 2. Self efficacy dalam kondisi tinggi, 3. Kreativitas mahasiswa dalam kondisi rendah, 3. Pengetahuan kewirausahaan berpengaruh positif terhadap sikap kreatif, 4. Self efficacy berpengaruh negatif terhadap kreativitas
\end{abstract}

\section{Keyword: Knowledge Entrepreneurship, Self efficacy, Creativity Student}

\section{PENDAHULUAN}

Menurut Biro Pusat Statistik Jawa Barat (BPS) pada Maret 2016 Jumlah penduduk miskin bulan Maret 2016 terjadi penurunan persentase penduduk miskin di perkotaan sebesar 0,91 persen yaitu dari 8,58\% menjadi 7,67 \%, di pedesaan terjadi kenaikan sebesar 0,19 persen yaitu dari 11,61 persen menjadi 11,80 persen (BPS Provinsi Jawa Barat tersedia http://pusdalisbang.jabarprov.go.id/pusdalisbang/beritastatistik-140.html). Garis kemiskinan Jawa Barat Maret 2016 sebesar Rp. 324.992,- mengalami peningkatan sebesar 2,01\% dibandingkan dengan garis kemiskinan bulan September 2015 sebesar Rp. 318.602,--

( BPS provinsi Jawa Barat: http://pusdalisbang.jabarprov.go.id/pusdalisbang/beritastatistik140.html)

Menurut Edy Suandi Hamid, Tingkat Pengangguran Terbuka (TPT) di Indonesia Agustus 2015 menapak 7,56 juta orang. Angka ini setara dengan 6,18 persen dari total 122,4 juta orang angkatan kerja. "Angka itu mengalami peningkatan dibanding TPT Februari 2015 sebesar 5,81 persen dan TPT Agustus 2014 sebesar 5,94 persen, sekitar 600 ribu penganggur terbuka itu lulusan perguruan tinggi sarjana,". Hal itu menunjukkan 
penyerapan tenaga kerja lulusan perguruan tinggi cenderung lambat terutama pengangguran berlabel sarjana.

(https://news.okezone.com/read/2015/12/30/65/1277253/7-5-juta-pengangguran-banyakbertitel-sarjana). Untuk mewujudkan tujuan tersebut tidaklah mudah, karena banyak faktor atau kendala yang harus dihadapi. Untuk mewujudkan tujuan di atas, UPI dituntut menghasilkan lulusan yang kreatif dan inovatif.Sehingga lulusannya mampu bersaing dengan lulusan perguruan tinggi lainnya serta dapat mensejahterakan lulusannya. Pengamatan awal terhadap 30 orang mahasiswa UPI Bandung, menunjukkan bahwa kreativitas mahasiswa cenderung masih rendah. Hal tersebut tampak pada tabel 1 sebagai berikut:

Tabel 1 Hasil Pra penelitian Tentang Kreativitas Mahasiswa UPI

\begin{tabular}{|l|l|l|}
\hline Kategori & F & $\%$ \\
\hline Tinggi & 9 & 36,73 \\
\hline Sedang & 7 & 23,33 \\
\hline Rendah & 14 & 46,6 \\
\hline & 30 & 100 \\
\hline
\end{tabular}

Sumber: Pra Penelitian 2016

Berdasarkan Tabel 1.1, tampak bahwa sebagian besar lulusan (46,33\%) memiliki kreativitas yang cenderung rendah. Hal ini menunjukkan bahwa sebagian besar lulusan kurang mampu menyesuaikan diri dengan perubahan maupun perkembangan IPTEK,sulit bersaing dalam memperoleh pekerjaan serta kreativitas untuk memperoleh sesuatu yang baru, kurang bisa mengembangkan keilmuannya dan tidak memiliki sikap terhadap perubahan. Kreativitas sangat erat dalam pendidikan kewirausahaan dan merupakan kunci utama untuk menumbuhkan jiwa wirausaha. Oleh karena itu peran pendidikan kewirausahaan sangat penting. Pendidikan kewirausahaan selama ini telah menjadi sorotan penting sebagai salah satu faktor untuk menumbuhkan dan mengembangkan hasrat, jiwa dan perilaku berwirausaha di kalangan generasi muda (Kourilsky dan Walstad, 1998). Terkait dengan pengaruh pendidikan kewirausahaan tersebut, diperlukan adanya pemahaman tentang bagaimana mengembangkan dan mendorong lahirnya wirausahawirausaha muda yang potensial sementara mereka berada di bangku sekolah. Pentingnya pendidikan kewirausahaan menjadi bagian penting sebagai penentu pembangunan ekonomi negara jangka panjang dewasa ini. Menurut GEM, aktivitas wirausaha yang baru lahir di Italia, Yunani dan Spanyol menurun rata-rata sebesar 20 persen selama periode 20082010, sementara di Prancis, Jerman dan Inggris mengalami kondisi kostan( Amorós Bosma, 2014). Hasil ini menunjukkan bahwa kurangnya pendidikan kewirausahaan menjadi hambatan bagi pemulihan ekonomi di negara-negara Eropa. Rendahnya aktivitas wirausahawan dijelaskan oleh Siemer (2014) dan Gourio dkk. (2014) bahwa penurunan wirausahawan yang signifikan menyebabkan pemulihan yang lambat melalui efek "generasi yang hilang". Sementara itu banyak perusahaan-perusahaan yang bangkrut, sebagian tumbuh dari waktu ke waktu dan berkontribusi pada penciptaan lapangan kerja 
"(Gourio et al., 2014, hal 2) serta memulihkan perekonomian negaranya. Dilaporkan juga oleh Ayres dan Raveendranathan (2015), bahwa tingkat lambat masuknya perusahaan setelah Resesi Besar di Amerika Serikat berdampak negatif pada pemulihan lapangan kerja dan kemajuan ekonomi. Peningkatan jumlah wirausahawan tidak lepas dari peran pendidikan persekolahan, baik tingkat SMK maupun perguruan tinggi. Hasil observasi yang dilakukan penulis pada 30 mahasiswa di Fakultas Pendidikan Ekonomi dan Bisnis UPI tentang faktor pendorong kreativitas berdasarkan Munandar (Akbar 2001:4) disajikan pada tabel 2 sebagai berikut:

Tabel 2

Prasurvey Faktor-faktor yang Mempengaruhi Kreativitas

\begin{tabular}{|l|l|l|}
\hline Faktor pendorong Kreativitas & frekuensi & $\%$ \\
\hline Membuat kombinasi baru & 15 & 50 \\
\hline $\begin{array}{l}\text { Banyak jawaban terhadap suatu } \\
\text { masalah }\end{array}$ & 8 & 26,67 \\
\hline $\begin{array}{l}\text { Kemampuan operasional dalam } \\
\text { berpikir }\end{array}$ & 7 & 23,33 \\
\hline Total & 30 & 100 \\
\hline
\end{tabular}

Sumber: data diolah

Berdasarkan tabel 2 tampak bahwa responden cenderung memiliki persepsi bahwa Kreativitas adalah membuat kombinasi baru. Padahal untuk membuat kombinasi baru memerlukan pengetahuan serta keyakinan mampu untuk membuat. Pengetahuan dan keyakinan mampu untuk membuat merupakan kemampuan operasional dalam berpikir. Hasil penelitian tentang kreativitas diantaranya dilakukan oleh Wang dan Chang (2005) bahwa Kemampuan, pengalaman, atau kreativitas pengusaha merupakan sumber perolehan pengetahuan. Terkadang, pengusaha lebih bersedia berbagi ilmu tentang PSNW daripada melindungi praktik mereka yang ada. Beberapa penulis (Subramaniam dan Youndt, 2005) telah menunjukkan bahwa hubungan positif ada antara Human Capital organisasi dan proses pengetahuan mereka (Andrikopoulos, 2005): proses akuisisi yang intens dan berkelanjutan Pengetahuan oleh para pengusaha yang berbagi pengetahuan tentang PSNWs bisa bermanfaat untuk memungkinkan hasil inovasi yang efektif Konsep ini bisa diterjemahkan ke dalam performa tingkat tinggi kegiatan mengingat $\mathrm{HC}$ sebagai faktor utama (Andrikopoulos, 2005).

Heny Dwi Astuti (2008) menemukan hubungan antara pengetahuan keperpustakaan dengan kreativitas guru dalam mengenlola perpustakaan SD di Kecamatan Banguntapan, kabupaten Bantul Yogyakarta terbukti memiliki hubungan positif dan signifikan yaitu sebesar 0,037. Demikian juga penelitian yang dilakukan Mertayasa (2017) hasilnya terdapat hubungan signifikan Knowledge Management terhadap Kreativitas mahasiswa jurusan pendidikan teknik informatika Undiksha semakin tinggi skor Knowledge Management maka semakin tinggi pula Kreativitas mahasiswa. Knowledge management berkontribusi $53.7 \%$ terhadap Kreativitas

Berdasarkan Theory of Planned Behavior (Ajzen,1991) bahwa sebuah perilaku dengan keterlibatan tinggi membutuhkan keyakinan dan evaluasi untuk menumbuhkan 
sikap, norma subyektif, dan kontrol perilaku dengan intensi sebagai mediator pengaruh berbagai faktor-faktor motivasional yang berdampak pada suatu perilaku. Keputusan berwirausaha merupakan perilaku dengan keterlibatan tinggi (high involvement) karena dalam mengambil keputusan akan melibatkan faktor Percaya pada kemampuan diri sendiri (Efikasi diri), bersikap positif (Sikap berperilaku), dan dukungan lingkungan (norma subyektif) (Ajzen(2008). Berdasarkan hasil pra survei maka peneliti akan mengimplementasikan aspek pengetahuan berwirausaha serta keyakinan mampu atau self efficacy terhadap kreativitas.

Berpikir kreatif sangat erat kaitannya dengan kreativitas mahasiswa dalam menggapai prestasi akademik di perguruan tinggi. Berpikir kreatif menghasilkan pemikiran-pemikiran yang baru, gagasan baru, karya baru, dan menemukan cara baru untuk menyelesaikan persoalan dan permasalahan yang ada. Untuk meningkatkan kreativitas, sangat diperlukannya cara pandang dalam mengelola sebuah pengetahuan. Mahasiswa yang telah mempelajari kewirausahaan diharapkan dapat berpikir kreatif dalam rangka menghasilkan pemikiran-pemikiran, gagasan dan karya baru. Di sinilah pentingnya pengetahuan berwirausaha.

Berpikir kreatif merupakan kemampuan untuk melihat bermacam-macam kemungkinan penyelesaian terhadap suatu masalah yang semakin kompleks, dimana individu harus mampu memikirkan, membentuk cara-cara baru atau mengubah cara-cara lama secara kreatif yang mencerminkan aspek fluency, flexibikity, originality dan elaboration agar dapat bertahan dalam persaingan yang semakin ketat. Self efficacy pada proses kognitif juga memungkinkan seseorang mengembangkan kemampuan berpikir kreatifnya. Mahasiswa dengan self efficacy yang tinggi akan menjadi tangguh dan menantang mereka menjadi orang yang kreatif. Seseorang harus memiliki self efficacy agar mempunyai keberanian untuk mempertahankan pendapatanya. Berdasarkan fenomena di atas, penulis akan mengkaji bagaimanakah pengaruh pengetahuan kewirausahaan dan self efficacy terhadap kreativitas mahasiswa UPI. Oleh karena itu akan dianalisis dengan judul penelitian Kontribusi Pengetahuan Kewirausahaan dan self efficacy terhadap Kreativitas mahasiswa FPEB UPI.

\section{Rumusan Masalah}

Berdasarkan latar belakang di atas, masalah yang akan dibahas dalam penelitian ini adalah sebagai berikut:

1. Bagaimanakah gambaran Pengetahuan Kewirausahaan, Self Efficacy dan Kreativitas mahasiswa UPI

2. Bagaimanakah pengaruh Pengetahuan Kewirausahaan terhadap Kreativitas pada mata mahasiswa UPI?

3. Bagaimanakah pengaruh Self Efficacy terhadap Kreativitas pada mahasiswa UPI

4. Bagaimanakah pengaruh Pengetahuan Kewirausahaan dan Self Efficacy terhadap Kreativitas mahasiswa UPI

\section{Tujuan Penelitian}


Adapun tujuan penelitian ini adalah untuk mengetahui dan mengkaji

1. Gambaran Pengetahuan Kewirausahaan, Self Efficacy dan Kreativitas mahasiswa UPI

2. Pengaruh Pengetahuan Kewirausahaan terhadap Kreativitas pada mata mahasiswa UPI?

3. Pengaruh Self Efficacy terhadap Kreativitas pada mahasiswa UPI

4. Pengaruh Pengetahuan Kewirausahaan dan Self Efficacy terhadap Kreativitas mahasiswa UPI

\section{Manfaat Penelitian}

Manfaat yang diharapkan dari penelitian ini adalah sebagai berikut :

1. Manfaat Secara Teoritis

a. Bagi pembaca, dapat menerima informasi dan menambah pengetahuan teori dan pengaruh Pengetahuan Kewirausahaan dan Self Efficacy terhadap Kreativitas.

b. Bagi peneliti selanjutnya, hasil penelitian ini dapat dijadikan masukan dalam pengembangan penelitian selanjutnya khususnya tentang kreativitas dilihat dari aspek lain selain variabel Pengetahuan Kewirausahaan dan Norma Sosial.

2. Manfaat Secara Praktis

a. Bagi instansi yang bersangkutan, dalam meningkatkan kreativitas harus memperhatikan tentang pengetahuan kewirausahaan dan norma sosial.

b. Menambah pemahaman kepada peneliti tentang pengetahuan kewirausahaan dan norma sosial.

\section{TINJAUAN PUSTAKA}

Treffinger telah mengembangkan teori dan model tingkat keberbakatan yang mencakup tiga tingkat kreativitas (Treffinger,1980:). Kreativitas tingkat pertama ini dapat diinterpretasikan sebagai person creativity. Maslow (Munandar,1988) mengemukakan bahwa orang-orang kreatif adalah pribadi-pribadi yang mampu mewujudkan dirinya (selfactualizing persons), orang tersebut sudah dapat memenuhi empat jenjang kebutuhan sebelumnya, yaitu kebutuhan biologis, rasa aman, sosialisasi, dan prestasi. Munandar (1988) berpendapat bahwa "kreativitas merupakan ungkapan unik dari keseluruhan kepribadian sebagai hasil interaksi individu dengan lingkungannya, yang tercermin dalam pikiran, perasaan, sikap atau perilakunya"..

Kreativitas Tingkat II ditandai oleh berpikir kompleks, demikian juga proses afektif yang memiliki ciri keterbukaan terhadap perasaan kompleks serta perkembangan nilai (Semiawan, 1996:51). MacKinnon mengemukakan bahwa salah satu sifat yang tidak terlihat dari orang yang betul-betul kreatif adalah ia melihat ada masalah, sementara orang lain tidak melihat adanya suatu masalah. Munandar (1988) mengemukakan bahwa "proses kreatif merupakan suatu proses yang tercermin dalam kelancaran, kelenturan, dan orijinalitas dalam berfikir". Proses kreatif tercermin dalam kemampuan berpikir kreatif. 
Kreativitas Tingkat III ditandai oleh internalisasi nilai, komitmen pada hidup produktif dan aktualisasi diri dalam kehidupan afektif. Dalam kehidupan kognitif ciri-ciri tersebut ditandai oleh inkuiri bebas, pengarahan diri dan manajemen sumber yang dimiliki serta pengembangan karya (product development), (Semiawan, 1990). Kreativitas tidak hanya ada pada bidang ilmiah saja, namun kreativitas dapat terjadi dalam semua bidang kehidupan. Dengan demikian produk dari kreativitas yang dihasilkan oleh seseorang atau sekelompok orang juga bermacam-macam bentuknya. Produk kreatif adalah sesuatu yang dialami atau dibuat oleh seseorang, misalnya ide, karya seni, teori baru, atau disain dari suatu gedung.

Berdasarkan kajian teoritis tentang kreativitas, merujuk kepada McKinnon, Gowan dan Treffinger (Jamridafrijal, 2010:8) maka dimensi pribadi kreatif dengan indikator fleksibel, menghargai fantasi, terbuka terhadap pengalaman, keterlibatan dalam tugas, kebebasan dalam penilaian, kepercayaan pada gagasan sendiri, kebebasan berekspresi serta minat terhadap aktivitas kreatif. Dimensi proses kreatif indikatornya adalah kelancaran dalam berpikir, keorsinilan dalam berpikir serta kelenturan dalam berpikir. Dimensi pendorong kreatif indikatornya adalah dorongan dari keluarga dan dorongan dari sekolah. Dimensi produk kreatif, indikatornya pengelolaan sumber baru, pengembangan sumber baru, pemecahan masalah serta memenuhi kebutuhan situasi

Dalam proses pembelajaran, kewirausahaan, bagi mahasiswa selain mendapatkan pengetahuan berwirausaha juga akan memperoleh pengetahuan tentang nilai-nilai kewirausahaan. Hal ini sesuai dengan pendapat Hasan (1996:248) menyatakan "Jika suatu disiplin ilmu diajarkan kepada seseorang atau sekelompok siswa, kalaupun tidak dinyatakan secara tersurat, tujuan yang berhubungan dengan nilai merupakan salah satu tujuan pendidikan disiplin itu". Pengetahuan kewirausahaan dalam studi ini diantaranya berdasarkan pengetahuan nilai-nilai kewirausahaan merujuk kepada karakteristik kewirausahaan menurut Meredith(Suryana, 2006: Alma, 2009) yaitu :percaya diri, berorintasi pada tugas dan hasil,keberanian mengambil resiko, kepemimpinan, berorintasi ke masa depan dan keorsinilan

Menurut Suryana,(2006:4)"Seorang wirausaha tidak akan berhasil apabila tidak memiliki pengetahuan, kemampuan dan kemauan. Ada kemauan tetapi tidak memiliki kemampuan dan pengetahuan tidak akan membuat seseorang menjadi wirausaha yang sukses. Sebaliknya memiliki pengetahuan dan kemampuan tetapi tidak disertai kemauan tidak akan membuat wirausaha mencapai kesuksesan".Pengetahuan yang harus dimiliki wirausaha yaitu Pengetahuan mengenai usaha yang akan dimasuki/ dirintis dan lingkungan usaha yang ada, pengetahuan tentang peran dan tanggung jawab dan pengetahuan tentang manajemen dan organisasi bisnis (Suryana,2006).

Self-efficacy mengacu pada keyakinan seseorang tentang kemampuannya untuk mengatur dan melakukan tindakan yang diperlukan untuk mencapai tujuan yang diharapkan. Bandura (1997: 37) menegaskan "self-efficacy is concerned not with the number of skills that you have, but with what you believe you can do with what you have under a variety of circumstances" artinya self-efficacy tidak berkaitan dengan jumlah 
keterampilan yang dimiliki seseorang, tetapi berkaitan dengan keyakinannya tentang apa yang dapat dilakukan orang tersebut dalam berbagai situasi.

Definisi yang hampir sama diungkapkan Wagner III dan Hollenbeck (2010: 93) "self-efficacy refer to judgements that people make about their ability to execute courses of action required to deal with prospective situations" artinya self-efficacy mengacu pada penilaian yang dibuat orang-orang tentang kemampuannya untuk melakukan serangkaian tindakan yang diperlukan dalam menghadapi sistuasi yang akan datang. Baron dan Byrne (2004: 183) menyatakan "self-efficacy adalah keyakinan seseorang terhadap kemampuan atau kompetensinya untuk melakukan sebuah tugas, mencapai tujuan, atau mengatasi hambatan". Berdasarkan pendapat para ahli tersebut dapat disimpulkan bahwa self-efficacy adalah keyakinan seseorang pada kemampuannya untuk merencanakan dan melakukan serangkaian tindakan yang diperlukan dalam rangka mencapai tujuan yang dikehendaki. Dalam studi ini self efficacy terdiri dari indikator: keyakinan akan potensi diri, keyakinan sukses kegiatan belajar yang dirintisnya dan keyakinan akan tetap survive

\section{Kerangka Pemikiran}

Pengetahuan yang dimiliki secara aktif dapat mendorong munculnya imajinasi yang memainkan bagian penting dalam tindakan yang kreatif (Suparman, 1994:62). Kreativitas sebagai kualitas pribadi merupakan hal yang diperlukan untuk penentuan masalah strategis dan pengembangan cara pemecahan masalah-masalah yang sedang dihadapi dalam suatu organisasi.

Keberhasilan perguruan tinggi salah satu indikatornya adalah para mahasiswa memiliki prestasi belajar yang baik. Hasil pembelajaran tersebut hanya dapat diperoleh dengan usaha yang maksimal dan berpikir kreatif yang menghasilkan kreativitas yang tinggi. berpikir kreatif merupakan bentuk pemikiran untuk menemukan jawaban, metodemetode, cara cara yang baru dalam menanggapi suatu persoalan untuk memecahkan masalah. Berpikir kreatif sangat erat kaitannya dengan kreativitas mahasiswa dalam menggapai prestasi akademik di perguruan tinggi. Berpikir kreatif menghasilkan pemikiran-pemikiran yang baru, gagasan baru, karya baru, dan nememukan cara baru untuk menyelesaikan persoalan dan permasalahan yang ada. Untuk meningkatkan kreativitas, sangat diperlukannya cara pandang dalam mengelola sebuah pengetahuan

Sternberg dan Williams (Chuang,2010) berpendapat bahwa untuk memaksimalkan dan mengembangkan kreativitas dibutuhkan suatu keyakinan diri. Kreativitas tanpa diiringi oleh keyakinan diri tidak dapat berkembang secara optimal. Individu dengan self eficacy yang tinggi akan dapat meningkatkan kreativitasnya dan dengan self eficacy, individu akan lebih kreatif dalam proses pemecahan masalah. Bandura (1997) menyebutkan beberapa hal yang dapat mempengaruhi self efficacy individu yaitu pencapaian prestasi, pengalaman orang lain, tingkat kesukaran tugas, status individu dalam lingkungan dan informasi mengenai kemampuan yang dimiliki. Oleh karena itu mahasiswa dengan self efficacy tinggi akan berusaha untuk dapat melaksanakan tugas, aktivitas atau tindakan tertentu dan terus berusaha apabila menemui hambatan dalam mencapai tujuan. Disamping itu mahasiwa yang mempunya self eficacy tingggi akan menciptakan karya-karya kreatif yang dapat dinikmati atau diguakan oleh masyarakat luas.

Manajerial, Januari 2017, Hal - 193

http://ejournal.upi.edu/index.php/manajerial/ 
Dengan kata lain self efficacy merupakan faktor penting untuk mengoptimalkan kreativitas. Sehingga mahasiswa tidak hanya membutuhkan kreativtas tetapi juga self efficacy agar ampu menghadapi tantangan dan persaingan era globalisasi dalam bidang pasar produk kreatif.

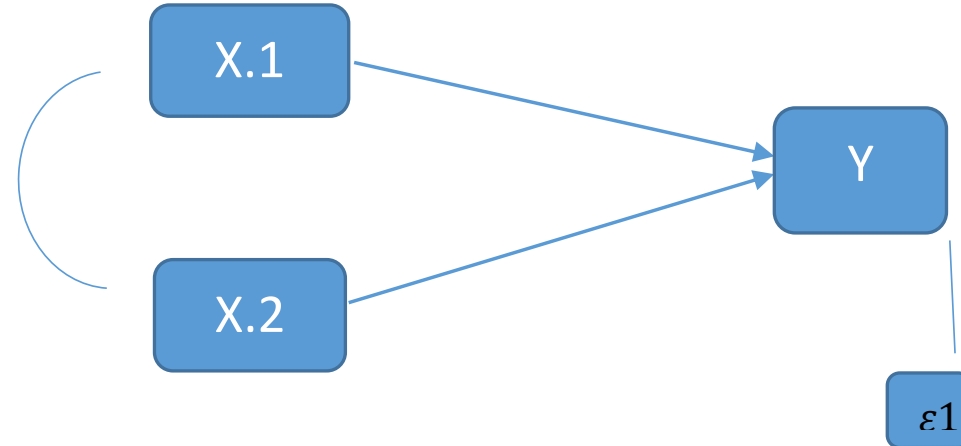

Gambar 1

Hubungan Antar Variabel

$\mathrm{X} .1=$ Pengetahuan Kewirausahaan

X.2= Norma Sosial

$\mathrm{Y}=$ Kreativitas

$\varepsilon 1=$ Pengaruh lain yang tidak ditelilti

Hipotesis

1. Pengetahuan Kewirausahaan berpengaruh positif terhadap Kreativitas.

2. Self Efficacy berpengaruh positif terhadap Kreativitas

3. Pengetahuan Kewirausahaan dan Self Efficacy secara bersama-sama berpengaruh positif terhadap Kreativitas

\section{Metode Penelitian}

Desain penelitian ini tergolong ke dalam rancangan noneksperimental, karena baik variabel bebas (independent variabel), maupun variabel terikat (dependent variabel) tidak di bawah pengendalian langsung peneliti (Kerlinger,1990:604). Berdasarkan variabel yang diteliti maka jenis penelitian ini merupakan penelitian verifikatif, berdasarkan jenis penelitiannya, maka metode penelitian yang akan digunakan adalah metode explanatory survey.

Populasi penelitian adalah mahasiswa S1 UPI yang tercatat sampai Bulan Agustus 2015 terdiri dari enam Fakultas dengan total sebesar 30.235 mahasiswa. Ukuran sampel dari 30235 mahasiswa dengan formulasi dari Isaac dan Michael (Sugiyono,2004:98) diperoleh ukuran sampel sebanyak 380 responden. 
Variabel-variabel dalam penelitian ini adalah Kreativitas (Y) sebagai variabel terikat, sedangkan Pengetahuan Kewirausahaan $\left(X_{1}\right)$, dan Self Efficacy $\left(X_{2}\right)$, sebagai variabel bebas.

Pengetahuan kewirausahaan yang dimaksud dalam penelitian ini adalah aspek nilainilai kewirausahaan dan pengetahuan berwirausaha yang diperoleh siswa setelah mengikuti perkuliahan kewirausahaan. Gambaran variabel ini diperoleh berdasarkan skor angket persepsi siswa terhadap pengetahuan kewirausahaan. Semakin tinggi skor seseorang, semakin tinggi tingkat persepsinya terhadap pengetahuan kewirausahaan. Pengetahuan Kewirausahaan $\left(X_{1}\right)$ merujuk pada Meredith (Suryana,2006:3), Alma (2002:39) Suherman (2008:42), yang terdiri dari dimensi nilai-nilai kewirausahaan $\left(X_{1.1}\right)$ indikatornya adalah: percaya diri, berorientansi pada tugas dan hasil, berani mengambil resiko, kepemimpinan, keorsinilan dan berorientasi ke depan. Dimensi pengetahuan berwirausaha $\left(X_{1.2}\right)$ dengan indikator: pengetahuan perencanaan usaha, pengetahuan pengambilan keputusan, pengetahuan mengelola perusahaan, pengetahuan mengatur keuangan, pengetahuan teknik/proses produksi, pengetahuan merancang produk, pengetahuan teknik memasarkan, pengetahuan mendistribusikan barang, pengetahuan administrasi pembukuan, pengetahuan teknik mengendalikan perusahaan. Data diukur dengan skala numerik, jenis data interval.

Self Efficacy dalam penelitian ini adalah keyakinannya tentang apa yang dapat dilakukan orang tersebut dalam berbagai situasi (Bandura, 1997:37). Self efficacy terdiri dari indikator: keyakinan akan potensi diri, keyakinan sukses kegiatan belajar yang dirintisnya dan keyakinan akan tetap survive. Gambaran variabel ini diperoleh berdasarkan skor angket persepsi siswa terhadap karakteristik self efficacy. Semakin tinggi skor seseorang, semakin tinggi tingkat persepsinya terhadap self efficacy.Data diukur dengan skala Numerik, jenis data interval.

Kreativitas dalam penelitian ini adalah kecenderungan mahasiswa dalam bertindak konsisten secara positif atau negatif terhadap kreativitas. Gambaran variabel ini diperoleh berdasarkan skor angket persepsi siswa terhadap karakteristik sikap kreatifnya. Semakin tinggi skor seseorang, semakin tinggi tingkat persepsinya terhadap sikap kreatif. Data diukur dengan skala sikap, jenis data Interval. Kreativitas (Y) merujuk kepada teori tingkat kreativitas dari Mc Kinnon (1970). Dimensi Kreativitas:dimensi pribadi kreatif indikatornya:fleksibel, menghargai fantasi, terbuka terhadap pengalaman, keterlibatan dalam tugas, kebebasan dalam penilaian, kepercayaan pada gagasan sendiri, kebebasan berekspresi serta minat terhadap aktivitas kreatif. Dimensi proses kreatif indikatornya: kelancaran berpikir, keorsinilan berpikir dan kelenturan berpikir. Dimensi pendorong kreatif indikatornya: dorongan keluarga dan dorongan sekolah. Dimensi produk kreatif, indikatornya: pengelolaan sumber baru, pengembangan sumber baru, pemecahan masalah dan memenuhi kebutuhan situasi. Data diukur dengan skala numerik, jenis data interval.

Alat pengumpulan data yang digunakan dalam penelitian ini adalah kuesioner. Kuesioner dalam penelitian ini dikonstruksi dalam tiga jenis angket meliputi Pengetahuan kewirausahaan diukur dengan skala numerik, lima pilihan dan self efficacy diukur dengan 
skala numerik, lima pilihan dan Kreativitas diukur dalam skala Likert dengan lima pilihan. Berikut hasil uji validitas disajikan pada tabel 3 sebagai berikut

\section{Tabel 3}

Jumlah Item Angket Hasil Ujicoba

\begin{tabular}{lllll}
\hline \multirow{2}{*}{ No } & Variabel & Jumlah Item Angket & \\
& & Sebelum di uji & Tidak valid & Valid \\
\hline 1 & Pengetahuan kewirausahaan & 32 & 4 & 28 \\
4 & Self Efficacy & 25 & 5 & 20 \\
5 & Sikap Kreatif & 32 & 6 & 26 \\
\hline \multicolumn{2}{l}{ Total } & & & \\
\hline
\end{tabular}

Sumber: data diolah

Hasil dari uji reliabilitas untuk setiap variabel disajikan pada tabel 4 berikut ini.

\section{Tabel 4}

\section{Daftar Nilai Koefisien Reliabilitas Setiap Variabel}

\begin{tabular}{lllll}
\hline Variabel & Korelasi & Koefisien & Sign $=30$ & Keterangan \\
Pengetahuan kewirausahaan & 0,84 & 0,91 & 0,361 & Reliabel \\
\hline Self Efficacy & 0,56 & 0,72 & 0,361 & Reliabel \\
Sikap Kreatif & 0,57 & 0,72 & 0,361 & Reliabel \\
\hline
\end{tabular}

Sumber: data diolah

Dalam analisis data, langkah yang harus ditempuh adalah Tahap pertama, analisis deskripsi yaitu untuk mendeskripsikan variabel-variabel yang mempengaruhi variabel terikat baik secara kuantitatif maupun kualitatif. Deskripsi dimaksudkan untuk memperoleh gambaran masing-masing variabel yang diamati, yaitu untuk melihat gambaran spesifik pengetahuan kewirausahaan, norma sosial dan kreativitas mahasiswa UPI. Untuk melakukan analisis deskripsi variabel-variabel tersebut maka diperlukan alat bantu seperti perhitungan persentase, tabel dan grafik, sehingga diperoleh persentase jawaban setiap alternatif jawaban dan skor rata-rata. Pertama, penyajian data hasil penelitian ini menggunakan tabel distribusi frekuensi. Kedua, untuk melihat kondisi variabel masing-masing penelitian, digunakan interpretasi skor. Skor alternatif jawaban angket yang terentang dari 1 sampai dengan 5, banyak kelas interval ditentukan sebanyak 5 kelas, panjang kelas intervalnya.

Tahap kedua, adalah uji hipotesis dan analisis terhadap variabel yang diamati. Untuk melakukan uji hipotesis, terlebih dahulu dilakukan pengujian normalitas.Uji normalitas adalah suatu bentuk pengujian tentang kenormalan distribusi data. Tujuannya untuk mengetahui data yang diambil berdistribusi normal dan untuk mengetahui bahwa sampel yang dijadikan objek penelitian mewakili populasi, sehingga hasil penelitian dapat digeneralisasikan pada populasi.

Apabila data tersebut berdistribusi normal maka dapat menggunakan statistik parametrik. Sedangkan, jika data tersebut tidak berdistribusi normal dapat menggunakan statistik nonparametrik. Untuk melihat normalitas data digunakan grafik distribusi, yaitu normal probability plot of standardized residual,jika menyebar di sekitar garis diagonal dan 
mengikuti arah garis diagonal atau grafik histogramnya menunjukkan pola distribusi normal, maka memenuhi asumsi normalitas. Dengan demikian hasil uji normallitas menunjukkan semua variabel dalam kondisi normal. Selanjutnya dilakukan analisis. Analisis dimaksudkan untuk memenuhi syarat yang diperlukan dalam analisis. Korelasi parsial digunakan untuk menganalisis bila peneliti bermaksud mengetahui pengaruh atau mengetahui hubungan antara variabel independen dan dependen, dimana salah satu variabel independennya dibuat tetap/dikendalikan (Sugiyono, 2014:235). Rumus yang digunakan untuk menentukan koefisien korelasi parsial sedangkan untuk menentukan pengaruh antara pengetahuan kewirausahaan dan self efficacy secara simultan terhadap kreativitas, maka korelasi yang digunakan adalah rumus korelasi berganda. Untuk menyatakan besar kecilnya sumbangan (kontribusi) variabel $\mathrm{X}$ terhadap $\mathrm{Y}$, rumus yang digunakan adalah rumus koefisien determinan. Sedangkan untuk menguji bagaimana pengaruh masing-masing variabel bebas terhadap variabel terikatnya digunakan uji t. Sedangkan uji F digunakan untuk menghitung pengaruh simultan variabel bebas secara keseluruhan terhadap variabel terikat

\section{HASIL PENELITIAN DAN PEMBAHASAN}

\section{Hasil Penelitian}

\section{Deskripsi Pengetahuan Kewirausahaan}

Gambaran empirik pengetahuan kewirausahaan dijabarkan ke dalam dimensi:(1) Nilainilai kewirausahaan sebanyak 12 item, (2) Pengetahuan berwirausaha, sebanyak 16 item yang dijabarkan lagi menjadi indikator-indikator yang dapat diukur. Berdasarkan perhitungan skor skala 5 digambarkan pada tabel 5 sebagai berikut:

\section{Tabel 5}

Tanggapan Responden Variabel Pengetahuan Kewirausahaan

\begin{tabular}{lllll}
\hline Jawaban & f & Bobot & Hasil & \% \\
\hline 5 & 119 & 5 & 595 & 1.947 \\
4 & 2155 & 4 & 8620 & 28.21 \\
3 & 5032 & 3 & 15096 & 49.41 \\
2 & 2909 & 2 & 5818 & 19.04 \\
1 & 425 & 1 & 425 & 1.391 \\
\hline & 10640 & & 30554 & 100 \\
\hline & & & Rata & 2.87
\end{tabular}

Sumber:data diolah

Berdasarkan tabel 5 variabel pengetahuan kewirausahaan memiliki skor rata-rata sebesar 2,87 dalam kategori sedang. Deskripsi masing-masing dimensi variabel pengetahuan kewirausahaan ditunjukkan pada tabel 6 sebaga berikut.

Tabel 6

Dimensi Variabel Pengetahuan Kewirausahaan

\begin{tabular}{llll}
\hline No & Dimensi & $\%$ & Keterangan \\
\hline 1 & Pengetahuan nilai-nilai kewirausahaan & 57,61 & Sedang \\
2 & Pengetahuan berwirausaha & 57,30 & Sedang \\
\hline
\end{tabular}




\section{Sumber: data diolah}

Berdasarkan tabel 6 menunjukkan bahwa dimensi pengetahuan nilai-nilai kewirausahaan paling tinggi dalam kategori sedang. Tanggapan responden terhadap indikator pengetahuan nilai-nilai kewirausahaan tampak pada tabel 7 berikut.

Tabel 7

Tanggapan Responden Dimensi Pengetahuan Nilai-nilai Kewirausahaan

\begin{tabular}{|c|c|c|c|c|c|c|}
\hline \multirow{2}{*}{$\begin{array}{l}\text { Indikator } \\
\text { Kewirausahaan }\end{array}$} & \multicolumn{5}{|c|}{ Skor Skala Nilai } & \multirow{2}{*}{$\begin{array}{l}\text { Keteranga } \\
\mathrm{n}\end{array}$} \\
\hline & Item & Mak & Ideal & skor & $\%$ & \\
\hline Percaya diri & 1 & 5 & 1900 & 1204 & 63.37 & Sedang \\
\hline Berorientasi pada hasil & 3 & 15 & 5700 & 3250 & 57.02 & Sedang \\
\hline Berani mengambil resiko & 2 & 10 & 3800 & 2180 & 57.37 & Sedang \\
\hline Kepemimpinan & 3 & 15 & 5700 & 3404 & 59.72 & Sedang \\
\hline Keorsinilan & 2 & 10 & 3800 & 2028 & 53.37 & Sedang \\
\hline Orientasi ke masa depan & 1 & 5 & 1900 & 1070 & 56.32 & Sedang \\
\hline Total & & & Rata-r & & 57,61 & Sedang \\
\hline
\end{tabular}

Sumber: data diolah

Tabel 7 di atas menunjukkan dimensi pengetahuan nilai-nilai kewirausahaan dalam kondisi sedang $(57,61 \%)$. Indikator paling tinggi adalah percaya diri sebesar $63,37 \%$ dan paling rendah adalah keorsinilan (53,37\%). Tanggapan responden terhadap indikator pengetahuan berwirausaha tampak pada tabel 8 sebagai berikut.

Tabel 8

Tanggapan Responden Dimensi PengetahuanBerwirausaha

\begin{tabular}{lllllll}
\hline Indikator Pengetahuan & \multicolumn{9}{l}{ Skor Skala Nilai } & & Keterangan \\
Berwirausaha & Item & Mak & Ideal & skor & $\%$ & \\
\hline Perencanaan Usaha & 1 & 5 & 1900 & 1093 & 57.53 & Sedang \\
Mengelola Usaha & 3 & 15 & 5700 & 3151 & 55.28 & Sedang \\
Mengatur Keuangan & 1 & 5 & 1900 & 1112 & 58.53 & Sedang \\
Teknik Produksi & 3 & 15 & 5700 & 3350 & 58.77 & Sedang \\
Merancang Produk & 1 & 5 & 1900 & 1191 & 62.68 & Sedang \\
Distribusi barang & 1 & 5 & 1900 & 1158 & 60.95 & Sedang \\
Administrasi pembukuan & 3 & 15 & 5700 & 3223 & 56.54 & Sedang \\
Mengendalikan Perusahaan & 2 & 10 & 3800 & 1971 & 51.87 & Sedang \\
Mempengaruhi orang lain & 1 & 5 & 1900 & 1169 & 61.53 & Sedang \\
\hline Total & 14 & \multicolumn{7}{c}{ Rata-rata } & 57,3 & sedang \\
\hline
\end{tabular}

Sumber: data diolah

Tabel 8 memperlihatkan bahwa pada umumnya dimensi pengetahuan berwirausaha sedang $(57,30 \%)$. Indikator paling tinggi adalah merancang produksi $(62,68 \%)$ dan yang paling rendah adalah mengendalikan perusahaan $(51,87 \%)$.

\section{Deskripsi Self Efficacy}

Gambaran empirik dari self efficacy dijabarkan ke dalam dimensi (1) keyakinan akan potensi diri, sebanyak 7item, (2) keyakinan kegiatan belajar yang dirintis sebanyak 7 item, 
(3) keyakinan tetap survive dalam keahlian yang dimiliki, sebanyak 3 item, yang dijabarkan lagi menjadi indikator-indikator yang dapat diukur. Berdasarkan perhitungan skor skala 5 digambarkan pada tabel 9 sebagai berikut:

\section{Tabel 9}

Tanggapan Responden Variabel Percaya Diri

\begin{tabular}{lllll}
\hline Jawaban & $\mathrm{f}$ & Bobot & Hasil & $\%$ \\
\hline 5 & 51 & 5 & 255 & 1.2579 \\
4 & 1961 & 4 & 7844 & 38.694 \\
3 & 3318 & 3 & 9954 & 49.102 \\
2 & 1089 & 2 & 2178 & 10.744 \\
1 & 41 & 1 & 41 & 0.2022 \\
\hline & 6460 & & 20272 & 100 \\
& & & Rata & 3,1381
\end{tabular}

Sumber: data diolah

Berdasarkan tabel 9 di atas, tanggapan mahasiswa UPI tentang self efficacy memiliki skor rata-rata sebesar 3,13 dalam kategori sedang. Deskripsi masing-masing dimensi, variabel self efficacy dijelaskan dengan tabel 10 sebagai berikut:

\section{Tabel 10}

Dimensi Self Efficacy

\begin{tabular}{|l|l|l|l|}
\hline No & Dimensi & $\%$ & Keterangan \\
\hline 1 & Keyakinan akan potensi diri & 63,26 & Sedang \\
\hline 2 & Keyakinan kesuksesan kegiatan & 62,37 & Sedang \\
\hline 3 & Keyakinan tetap survive & 62,51 & Sedang \\
\hline
\end{tabular}

Sumber: data diolah

Berdasarkan tabel 10 dimensi keyakinan akan potensi diri $(63,26 \%)$ sebagai skor paling tinggi dalam kondisi sedang. Tanggapan responden terhadap indikator keyakinan akan potensi diri tampak pada tabel sebagai berikut.

Tabel

Tanggapan Responden Dimensi Keyakinan Akan Potensi Diri

\begin{tabular}{llllllll}
\hline \multirow{2}{*}{ Indikator keyakinan akan potensi diri } & \multicolumn{3}{l}{ Skor Skala Nilai } & & \multirow{2}{*}{ Keterangan } \\
& Item & Iak & Ideal & f & $\%$ & \\
\hline Potensi menjadi wirausaha & 1 & 5 & 1900 & 1205 & 63.42 & Sedang \\
Menjadi wirausahawan yang berhasil & 2 & 10 & 3800 & 2355 & 61.97 & Sedang \\
Memiliki bakat dalam wirausaha & 2 & 10 & 3800 & 2410 & 63.42 & Sedang \\
Memiliki karakter wirausaha & 2 & 10 & 3800 & 2444 & 64.32 & Sedang \\
\hline Total & \multicolumn{4}{c}{ Rata-rata } & 63,26 & Sedang \\
\hline
\end{tabular}

Sumber: data diolah

Tabel di atas memperlihatkan bahwa pada umumnya dimensi keyakinan akan potensi diri dalam kondisi sedang $(63,76 \%)$. Indikator yang dinilai relatif paling tinggi 
adalah memiliki karakter wirausaha $(64,32 \%)$ dan yang paling rendah adalah menjadi wirausahawan yang berhasil $(61,97 \%)$. Tanggapan responden terhadap dimensi keyakinan kesuksesan kegiatan tampak pada tabel 11 sebagai berikut.

Tabel 11

Tanggapan Responden Dimensi Keyakinan Kesuksesan Kegiatan

\begin{tabular}{|c|c|c|c|c|c|c|}
\hline \multirow{2}{*}{$\begin{array}{l}\text { Indikator } \\
\text { kegiatan }\end{array}$} & \multicolumn{5}{|c|}{ Skor Skala Nilai } & \multirow[t]{2}{*}{ Keterangan } \\
\hline & Item & Mak & Ideal & $\mathrm{f}$ & $\%$ & \\
\hline Usaha yang dirintisnya sukses & 1 & 5 & 1900 & 1218 & 64.11 & Sedang \\
\hline Mengatasi kesulitan yang timbul & 2 & 10 & 3800 & 2426 & 63.84 & Sedang \\
\hline Bersaing dengan lulusan PT lainnya & 2 & 10 & 3800 & 2378 & 62.58 & Sedang \\
\hline Mendapat kepercayaan dari mitranya & 2 & 10 & 3800 & 2273 & 59.82 & Sedang \\
\hline Total & 7 & & Rata- & & 62,37 & Sedang \\
\hline
\end{tabular}

Sumber: data diolah

Tabel 11 memperlihatkan bahwa pada umumnya dimensi keyakinan kesuksesan kegiatan dalam kondisi sedang $(62,37 \%)$. Indikator yang dinilai relatif paling tinggi adalah usaha yang dirintisnya sukses $(64,32 \%)$ dan yang paling rendah adalah mendapat kepercayaan dari mitra $(59,82 \%)$. Tanggapan responden terhadap dimensi keyakinan tetap survive tampak pada tabel 12 sebagai berikut.

\section{Tabel 12}

Tanggapan Responden Dimensi Keyakinan Tetap Survive

\begin{tabular}{|c|c|c|c|c|c|c|}
\hline \multirow{2}{*}{ Indikator keyakinan tetap survive } & \multicolumn{5}{|c|}{ Skor Skala Nilai } & \multirow[t]{2}{*}{ Keterangan } \\
\hline & Item & Mak & Ideal & $\mathrm{f}$ & $\%$ & \\
\hline $\begin{array}{l}\text { kelangsungan hidup wirausaha yang } \\
\text { dirintis }\end{array}$ & 1 & 5 & 1900 & 1197 & 63,00 & Sedang \\
\hline belajar wirausaha akan berkembang & 2 & 10 & 3800 & 2366 & 62.26 & Sedang \\
\hline Total & 3 & & Rata- & & 62,51 & Sedang \\
\hline
\end{tabular}

Sumber: data diolah

Tabel 12 memperlihatkan bahwa pada umumnya dimensi keyakinan keyakinan tetap survive dalam kondisi sedang $(62,51 \%)$. Indikator yang dinilai relatif paling tinggi adalah kelangsungan hidup wirausaha yang dirintis(63\%) dan yang paling rendah adalah keyakinan belajar wirausaha akan berkembang $(62,26 \%)$.

\section{Deskripsi Kreativitas}

Gambaran empirik dari sikap kreatif mahasiswa UPI dijabarkan ke dalam dimensi (1) Pribadi kreatif sebanyak 14 item, (2) Proses Kreatif sebanyak 3 item, (3) Pendorong kreatif, sebanyak 5 item, dan(4) Produk Kreatif sebanyak 4 (item) yang dijabarkan lagi menjadi indikator-indikator yang dapat diukur. Berdasarkan perhitungan skor skala 5

digambarkan pada tabel 13 sebagai berikut:

Tabel 13

Tanggapan RespondenVariabel Kreativitas

\begin{tabular}{lllll}
\hline Jawaban & f & Bobot & Hasil & $\%$ \\
\hline 5 & 111 & 5 & 555 & 1.89
\end{tabular}




\begin{tabular}{lllll}
4 & 2060 & 4 & 8240 & 28.1 \\
3 & 5445 & 3 & 16335 & 55.8 \\
2 & 1900 & 2 & 3800 & 13 \\
1 & 364 & 1 & 364 & 1.24 \\
\hline & 9880 & & 29294 & 100 \\
& & & Rata & 2.96 \\
\hline
\end{tabular}

Sumber: data diolah

Berdasarkan tabel 13 di atas, dapat diperoleh keterangan bahwa sebagian besar tanggapan mahasiswa UPI tentang kreativitas dengan kategori sedang. Analisis masing-masing dimensi, dijelaskan dengan tabel 14 sebagai berikut:

Tabel 14

Dimensi Variabel Kreativitas

\begin{tabular}{llll}
\hline No & Dimensi & $\%$ & Keterangan \\
\hline 1 & Pribadi Kreatif & 58,25 & Sedang \\
2 & Proses Kreatif & 41,39 & rendah \\
3 & Pendorong Kreatif & 59,4 & Sedang \\
4 & Produk Kreatif & 65,93 & Sedang \\
\hline
\end{tabular}

Sumber: data diolah

Berdasarkan tabel 14, dimensi produk kreatif sebagai dimensi paling dominan sebesar $65,93 \%$. Tanggapan responden dimensi pribadi kreatif tampak pada tabel 20 sebagai berikut.

\section{Tabel 15}

Tanggapan Responden Dimensi Pribadi Kreatif

\begin{tabular}{lclllll}
\hline \multirow{2}{*}{ Indikator Pribadi Kreatif } & \multicolumn{3}{c}{ Skor Skala Nilai } & & \multirow{2}{*}{ Keterangan } \\
& Item & Mak & Ideal & skor & $\%$ & \\
\hline Menghargai fantasi & 2 & 10 & 3800 & 2296 & 60.42 & Sedang \\
Fleksibel & 1 & 5 & 1900 & 1131 & 59.53 & Sedang \\
Terbuka terhadap pengalaman & 1 & 5 & 1900 & 1127 & 59.32 & Sedang \\
Keterlibatan dalam tugas & 2 & 10 & 3800 & 2176 & 57.26 & Sedang \\
Kepercayaan pada gagasansendiri & 2 & 10 & 3800 & 2002 & 52.68 & Rendah \\
Kebebasan dalam penilaian & 2 & 10 & 3800 & 2302 & 60.58 & Sedang \\
Kebebasan berekspresi & 2 & 10 & 3800 & 2278 & 59.95 & Sedang \\
Minat terhadap aktivitas kreatif & 2 & 10 & 3800 & 2182 & 57.42 & Sedang \\
\hline & 14 & \multicolumn{9}{l}{ Rata-rata } & 58,25 & Sedang \\
\hline
\end{tabular}

Sumber: data diolah

Berdasarkan tabel 15 kondisi dimensi pribadi kreatif sedang $(58,25 \%)$.Indikator paling tinggi adalah kebebasan dalam penilaian $60,58 \%$.Sedangkan yang paling kecil adalah minat terhadap aktivitas kreatif sebesar $57,42 \%$. Tanggapan responden terhadap dimensi proses kreatif pada tabel 16 sebagai berikut. 


\section{Tabel 16}

Tanggapan Responden Dimensi Proses Kreatif

\begin{tabular}{lllllll}
\hline \multirow{2}{*}{ Indikator Proses Kreatif } & \multicolumn{3}{c}{ Skor Skala Nilai } & \multicolumn{3}{c}{ Keterangan } \\
& Item & Mak & Ideal & skor & $\%$ & \\
\hline Kelancaran dalam berpikir & 2 & 10 & 3800 & 1054 & 27.74 & rendah \\
Keorsinilan dalam berpikir & 1 & 5 & 1900 & 1065 & 56.05 & Sedang \\
Kelenturan dalam berpikir & 1 & 5 & 1900 & 1027 & 54.05 & Sedang \\
\hline & \multicolumn{1}{c}{ Rata-rata } & 54,07 & Sedang \\
\hline
\end{tabular}

Sumber: data diolah

Berdasarkan tabel 17 dimensi proses kreatif sedang (54,07\%). Dimensi proses kreatif paling tinggi adalah indikator keorsinilanberpikir $(56,05 \%)$ sedangkan yang paling kecil adalah kelancaran dalam berpikir $(27,74 \%)$. Tanggapan responden terhadap dimensi pendorong kreatif tampak pada tabel 17 sebagai berikut.

Tabel 17

Tanggapan Responden Dimensi Pendorong Kreatif

\begin{tabular}{|c|c|c|c|c|c|c|c|}
\hline Indikator & Pendorong & Skor & ala N & & & & Keterangan \\
\hline Kreatif & & Item & Mak & Ideal & skor & $\%$ & \\
\hline Sekolah & & 1 & 5 & 1900 & 1106 & 58.21 & Sedang \\
\hline Keluarga & & 4 & 10 & 7600 & 4537 & 59.7 & Sedang \\
\hline Total & & 5 & & Rata-1 & & 59,4 & \\
\hline
\end{tabular}

Sumber: data diolah

Berdasarkan tabel 18 dimensi pendorong kreatif dalam kategori sedang sebesar 59,4\%. Indikator paling tinggi adalah keluarga $(59,7 \%)$ sedangkan yang paling rendah adalah sekolah sebesar $58,21 \%$. Tanggapan responden terhadap dimensi produk kreatif pada tabel 18 sebagai berikut.

Tabel 18

Tanggapan RespondenDimensi Produk Kreatif

\begin{tabular}{lllllll}
\hline & \multicolumn{3}{l}{ Skor Skala Nilai } & & & Keteranga \\
Indikator Produk Kreatif & Ite & & & & $\mathrm{n}$ \\
& $\mathrm{m}$ & Mak & Ideal & skor & $\%$ & \\
\hline Pengembangan produk baru & 1 & 5 & 1900 & 1180 & 62.11 & Sedang \\
Pengelolaan sumber baru & 1 & 5 & 1900 & 1214 & 63.89 & Sedang \\
Pemecahan masalah & 1 & 5 & 1900 & 1274 & 67.05 & Sedang \\
Memenuhi kebutuhan situasi & 1 & 5 & 1900 & 1343 & 70.68 & Sedang \\
\hline & \multicolumn{1}{l}{ Rata-rata } & 65,93 & Sedang \\
\hline
\end{tabular}

Sumber: data diolah

Tabel 18 memperlihatkan bahwa dimensi produk kreatif dalam kondisi sedang sebesar 59,48\%. Indikator paling tinggi adalah memenuhi kebutuhan situasi sebesar $70,68 \%$,sedangkan paling kecil adalah pengembangan produk baru $62,11 \%$. 


\section{Pengujian Persyaratan Analisis Data}

Untuk mengetahui apakah model penelitian tersebut layak atau tidak, maka dilakukan asumsi klasik yang meliputi uji normalitas. Uji normalitas menggunakan metode Kolmogorov-Smirnov, hasil uji normalitas Menunjukkan bahwa variabel pengetahuan kewirausahaan, self efficacy dan kreativitas memiliki distribusi normal, dengan hasil analisis tingkat kepercayaan 95\% menunjukkan bahwa semua variabel terdistribusi normal. Kriteria pengambilan keputusannya adalah sebagai berikut:

a. Jika probabilitas atau signifikansi lebih kecil dari 0.05 maka sampel berasal dari populasi yang tidak berdistribusi normal.

b. Jika probabilitas atau signifikansi lebih besar dari 0.05 maka sampel berasaldari pupulasi yang berdistribusi normal.

Uji kenormalan dengan menggunakan statistik uji Kolmogorov-Smirnov k. Berdasarkan kriteria pengujian dan tabel 4.6 nampak bahwa nilai signifikansi atau probabilitas dari populasi pretes dan postes masing-masing sebesar 0.200 dan 0.101 . Nilai signifikansi tersebut lebih besar dari 0.05, dengan demikian menurut statistik uji Kolmogorov-Smirnov $k$ kedua sampel berasal dari populasi yang berdistribusi normal. Hal ini disajikan pada tabel 19 sebagai berikut.

Tabel 19

Tabel uji Normalitas Kolmogorov Smirnov

\begin{tabular}{lllllll}
\hline \multicolumn{9}{l}{ Tests of Normality } \\
\multicolumn{9}{c}{ Kolmogorov-Smirnov } \\
& Statistic & df & Sig. & Statistic & df & Sig. \\
X.1 &, 074 & 380 &, 000 &, 984 & 380 &, 000 \\
X.2 &, 064 & 380 &, 001 &, 985 & 380 &, 000 \\
Y &, 055 & 380 &, 009 &, 992 & 380 &, 042 \\
\hline
\end{tabular}

a. Lilliefors Significance Correction

\section{PENGUJIAN HIPOTESIS}

Tabel 20

\section{Uji Korelasi Parsial}

Pengetahuan Kewirausahaan dengan Kreativitas

\begin{tabular}{|c|c|c|c|c|}
\hline \multicolumn{5}{|c|}{ Correlations } \\
\hline \multirow{3}{*}{\multicolumn{2}{|c|}{ Variabel kontrol }} & & & Pengetahuan \\
\hline & & & Kreati & Kewirausah \\
\hline & & & $\mathrm{S}$ & an \\
\hline \multirow{4}{*}{$\begin{array}{l}\text { Self } \\
\text { efficacy }\end{array}$} & Kreativitas & Correlation & 1,000 & ,420 \\
\hline & & $\begin{array}{l}\text { Significance } \\
\text { tailed) }\end{array}$ & $(2-$. & ,000 \\
\hline & & df & 0 & 337 \\
\hline & Pengetahuan & Correlation & ,420 & 1,000 \\
\hline
\end{tabular}




\begin{tabular}{llll} 
Kewirausahaan & $\begin{array}{l}\text { Significance } \\
\text { tailed })\end{array}$ & $(2-, 000$ & $\cdot$ \\
\cline { 2 - 4 } & $\mathrm{df}$ & 337 & 0 \\
\hline
\end{tabular}

Berdasarkan tabel 20 dapat diketahui bahwa hasil perhitungan koefisien korelasi antara variabel pengetahuan kewirausahaan terhadap kreativitas dimana self eficcacy dianggap tetap adalah sebesar 0,420. Hal tersebut menunjukan bahwa pengetahuan kewirausahaan memiliki hubungan yang sedang dan positif dengan kreativitas, artinya kenaikan pengetahuan kewirausahaan akan diikuti dengan kenaikan kreativitas. Dengan demikian, dapat diindikasikan bahwa penngetahuan kewirausahaan mempengaruhi kreativitas. Apabila pengetahuan mahasiswa FPEB mengalami peningkatan, maka kreativitas akan meningkat pula, begitu pula sebaliknya.

Tabel 21

Uji Korelasi Parsial

Self efficacy dengan Kreativitas

\begin{tabular}{|c|c|c|c|c|}
\hline \multicolumn{5}{|l|}{ Correlations } \\
\hline \multirow{2}{*}{\multicolumn{3}{|c|}{ Variabel kontrol }} & \multicolumn{2}{|c|}{ Kreativita } \\
\hline & & & $\mathrm{s}$ & Self Efficacy \\
\hline Pengetahuan & Kreativitas & Correlation & 1,000 &, 251 \\
\hline \multirow[t]{5}{*}{ Kewirausahaan } & & $\begin{array}{l}\text { Significance } \\
\text { tailed) }\end{array}$ & $(2-$. & ,000 \\
\hline & & df & 0 & 337 \\
\hline & Self Efficacy & Correlation &, 251 & 1,000 \\
\hline & & $\begin{array}{l}\text { Significance } \\
\text { tailed) }\end{array}$ & $(2-, 000$ & . \\
\hline & & $\mathrm{df}$ & 337 & 0 \\
\hline
\end{tabular}

Berdasarkan tabel 21, dapat diketahui bahwa hasil perhitungan koefisien korelasi antara variabel self efficacy terhadap kreativitas dimana pengetahuan kewirausahaan dianggap tetap adalah sebesar 0,251. Hal tersebut menunjukan bahwa self efficacy memiliki hubungan yang sedang dan positif dengan kreativitas, artinya kenaikan self efficacy akan diikuti dengan kenaikan kreativitas. Dengan demikian, dapat diindikasikan bahwa self efficacy mempengaruhi kreativitas. Apabila self efficacy mahasiswa FPEB mengalami peningkatan, maka kreativitas akan meningkat pula, begitu pula sebaliknya.

\section{Korelasi Ganda (Multiple Correlation)}

Uji korelasi ganda berfungsi untuk mencari pengaruh variabel $\mathrm{X}$ secara bersama-sama terhadap Y, yaitu pengaruh pengetahuan kewirausahaan dan self efficacy terhadap kreativitas secara bersama-sama. Hasil perhitungan korelasi ganda dilakukan menggunakan bantuan program IBM SPSS versi 23 sebagai berikut: 
Tabel 22

Uji Korelasi Ganda

Pengetahuan Kewirausahaan, Self Efikasi Terhadap Kreativitas

\section{Model Summary ${ }^{\mathrm{b}}$}

Model

Change Statistics

R Adjusted RStd. Error ofR SquareF $\mathrm{R}$ Square Square

$\operatorname{dim} 1 \quad$, 231 ensi a

on0 the Estimate Change Change df1 5,825 57,9972

df2 Change Watson

377,000 1,736

a. Predictors: (Constant), X.2, X.1

b. Dependent Variable: Y

Berdasarkan tabel 22 dapat diketahui hasil perhitungan korelasi ganda antara variabel pengetahuan kewirausahaan dan self efficacy terhadap kreativitas sebesar 0,235 dan nilai probabilitas (Sig. $\left.\mathrm{F}_{\text {change }}\right)=0,000$. Karena nilai maka keputusannya adalah Sig. $\mathrm{F}_{\text {change }}<0,05$ pengetahuan kewirausahaan dan self efficacy memiliki hubungan yang kuat secara simultan terhadap kreativitas. Dengan demikian, dapat diindikasikan pengetahuan kewirausahaan dan self efficacy mempengaruhi kreativitas. Jika pengetahuan kewirausahaan dan self efficacy mahasiswa FPEB mengalami peningkatan, maka kreativitas mahasiswa akan meningkat pula, begitu pula sebaliknya.

\section{PEMBAHASAN}

Berdasarkan hasil analisis terhadap data diperoleh hasil analisis dekriptif sebagai berikut. Variabel Pengetahuan kewirausahaan dalam kondisi sedang. Dimensi Pengetahuan Nilai-nilai Kewirausahaan. Indikator paling tinggi adalah percaya diri sebesar 63,37 \% dan paling rendah adalah keorsinilan (53,37\%). Dimensi pengetahuan berwirausaha sedang $(57,30 \%)$. Indikator paling tinggi adalah merancang produksi $(62,68 \%)$ dan yang paling rendah adalah mengendalikan perusahaan $(51,87 \%)$. Self efficacy dalam kondisi sedang. Dimensi keyakinan akan potensi diri $(63,26 \%)$ sebagai skor paling tinggi sedangkan dimensi keyakinan kesuksesan kegiatan paling rendah ( 62,37\%) semuanya dalam kondisi sedang. Dimensi keyakinan akan potensi diri dalam kondisi sedang $(63,76 \%)$. Indikator yang dinilai relatif paling tinggi adalah memiliki karakter wirausaha $(64,32 \%)$ dan yang paling rendah adalah menjadi wirausahawan yang berhasil $(61,97 \%)$ dimensi keyakinan kesuksesan kegiatan dalam kondisi sedang $(62,37 \%)$. Indikator yang dinilai relatif paling tinggi adalah usaha yang dirintisnya sukses(64,32\%) dan yang paling rendah adalah mendapat kepercayaan dari mitra $(59,82 \%)$. Dimensi keyakinan keyakinan tetap survive dalam kondisi sedang $(62,51 \%)$. Indikator yang dinilai relatif paling tinggi adalah kelangsungan hidup wirausaha yang dirintis(63\%) dan yang paling rendah adalah keyakinan belajar wirausaha akan berkembang $(62,26 \%)$. Kondisi kreativitas secara keseluruhan dalam kondisi sedang. Dimensi pribadi kreatif dalam kondisi sedang $(58,25 \%)$.Indikator paling tinggi adalah kebebasan dalam penilaian 60,58\%.Sedangkan 
yang paling kecil adalah minat terhadap aktivitas kreatif sebesar 57,42\%. Dimensi proses kreatif sedang $(54,07 \%)$. Dimensi proses kreatif paling tinggi adalah indikator keorsinilan berpikir $(56,05 \%)$ sedangkan yang paling kecil adalah kelancaran dalam berpikir $(27,74 \%)$. Dimensi pendorong kreatif dalam kategori sedang sebesar 59,4\%. Indikator paling tinggi adalah keluarga $(59,7 \%)$ sedangkan yang paling rendah adalah sekolah sebesar 58,21\%. Dimensi produk kreatif dalam kondisi sedang sebesar 59,48\%. Indikator paling tinggi adalah memenuhi kebutuhan situasi sebesar 70,68\%,sedangkan paling kecil adalah pengembangan produk baru $62,11 \%$.

Berikut ini analisis inferensial pengaruh pengetahuan kewirausahaan dan self efficacy terhadap Kreativitas. Pertama, pengetahuan kewirausahaan mempunyai hubungan postif dengan kreativitas mahasiswa $(\mathrm{r}=0,420)$, makin pengetahuan kewirausahaan, maka makin tinggi kreativitas mahasiswa. Sesuai penyataan Menurut Suryana,(2006:4)"Seorang wirausaha tidak akan berhasil apabila tidak memiliki pengetahuan, kemampuan dan kemauan. Keberhasilan wirausaha karena memiliki sikap kreatif. Juga sependapatn dengan Suparman, (1994:62) bahwa pengetahuan yang dimiliki secara aktif dapat mendorong munculnya imajinasi yang memainkan bagian penting dalam tindakan yang kreatif. Kreativitas sebagai kualitas pribadi merupakan hal yang diperlukan untuk penentuan masalah strategis dan pengembangan cara pemecahan masalah-masalah yang sedang dihadapi dalam suatu organisasi.

Variabel kreativitas mahasiswa dapat dijelaskan oleh variabel pengetahuan kewirausahaan sebesar $17,64 \%$. Hal ini berarti bahwa pengetahuan kewirausahaan merupakan variabel penting untuk diperhatikan dalam menjelaskan variabel kreativitas mahasiswa dalam kegiatan berwirausaha. Banyak cara yang dapat diterapkan untuk mengembangkan dan meningkatkan pengetahuan kewirausahaan, karena pengetahuan adalah sumber mendasar terhadap diri, serta merupakan sumber munculnya nilai-nilai, disamping menumbukan kompetensi (Hasan (1996:248). Oleh karena itu dalam pembelajaran selain diberikan aspek kompetensi/ pengetahuan yang diperoleh juga diperlukan muatan-muatan nilai-nilai kewirausahaan pelajaran tersebut, sehingga dengan nilai-nilai kewirausahaan, kreativitas mahasiswa dapat meningkat sehingga menambah semangat untuk berwirausaha. Kedua, self efficacy mempunyai hubungan positif dengan kreativitas mahasiswa $(\mathrm{r}=0,251)$, berarti makin tinggi self efficacy, maka makin tinggi kreativitas mahasiswa dalam kegiatan berwirausaha. Self efficacy banyak dipengaruhi keyakinan seseorang terhadap kemampuan atau kompetensinya untuk melakukan sebuah tugas, mencapai tujuan, atau mengatasi hambatan(Baron dan Byrne (2004: 183)). Seseorang yang memilki self efficacy mengarahkan emosinya menjadi motivasi yang mengarah tindakan yang diperlukan dalam rangka mencapai tujuan yang dikehendaki. Self efficacy inilah yang menimbulkan keyakinan seseorang untuk berhasil dalam tindakannya. Keberhasilan ini karena ditunjang oleh keyakinan untuk bertindak dalam berbagai situasi. Hal ini sesuai dengan pendapat Bandura, (1997:37) bahwa self-efficacy tidak berkaitan dengan jumlah keterampilan yang dimiliki seseorang, tetapi berkaitan dengan keyakinannya tentang apa yang dapat dilakukan orang tersebut dalam berbagai situasi.

Manajerial, Januari 2017, Hal - 206

http://ejournal.upi.edu/index.php/manajerial/ 
Variabel kreativitas mahasiswa dapat dijelaskan oleh self efficacy sebesar 6,30\%, berarti self efficacy merupakan variabel penting untuk diperhatikan dalam menjelaskan variabel kreativitas mahasiswa. Ini sesuai dengan kajian teoritis sebelumnya telah dikemukakan bahwa kreativitas ditentukan oleh self efficacy yang dimilikinya. mahasiswa yang memiliki self efficacy kuat akan selalu memerima kritik dan saran dari luar, serta telah mempersiapkan diri secara matang tentang hal-hal yang akan terjadi di lapangan. Ketiga, pengetahuan kewirausahaan dan self efficacy secara bersama-sama mempengaruhi kreativitas mahasiswa, yang dinyatakan dengan harga $\mathrm{R}^{2}=0,235$ artinya peningkatan kreativitas mahasiswa yang merupakan variabel terikat dapat diprediksi melalui variabel bebas yaitu pengetahuan kewirausahaan dan self efficacy. Pengetahuan kewirausahaan yang tinggi akan terlihat dari perilaku kehidupan mahasiswa yang bekerja keras, penuh tanggung jawab, ulet, dan mandiri. Unsur-unsur tersebut bila dimiliki mahasiswa akan sangat membantu dalam melakukan pekerjaan sehari-hari seperti melakukan kegiatan jasa, dagang atau manufaktur. Mahasiswa selain kompeten karena menguasai pengetahuan yang dimilikinya, juga dengan nilai-nilai kewirausahaan akan menjadi pendorong dalam melakukan berbagai kegiatan usaha.

Pengetahuan kewirausahaan yang tinggi tidak sekedar diukur dengan nilai kuantitatif tetapi ditunjang dengan nilai-nilai kewirausahaan. Keberhasilan perguruan tinggi salah satu indikatornya adalah para mahasiswa memiliki prestasi belajar yang baik. Hasil pembelajaran tersebut hanya dapat diperoleh dengan usaha yang maksimal dan berpikir kreatif yang menghasilkan kreativitas yang tinggi. berpikir kreatif merupakan bentuk pemikiran untuk menemukan jawaban, metode-metode, cara cara yang baru dalam menanggapi suatu persoalan untuk memecahkan masalah. Berpikir kreatif sangat erat kaitannya dengan kreativitas mahasiswa dalam menggapai prestasi akademik di perguruan tinggi. Berpikir kreatif menghasilkan pemikiran-pemikiran yang baru, gagasan baru, karya baru, dan nememukan cara baru untuk menyelesaikan persoalan dan permasalahan yang ada. Untuk meningkatkan kreativitas, sangat diperlukannya cara pandang dalam mengelola sebuah pengetahuan

Self efficacy merupakan salah satu unsur kepribadian yang perlu dimiliki oleh mahasiswa dalam keyakinan mampu berhasil dalam tindakan terhadap suatu obyek. Hal ini sesuai dengan pendapat Sternberg dan Williams (1996) bahwa untuk memaksimalkan dan mengembangkan kreativitas dibutuhkan suatu keyakinan diri (Chuang,2010). Kreativitas tanpa diiringi oleh keyakinan diri tidak dapat berkembang secara optimal. Individu dengan self eficacy yang tinggi akan dapat meningkatkan kreativitasnya dan dengan self eficacy, individu akan lebih kreatif dalam proses pemecahan masalah. Bandura (1997) menyebutkan beberapa hal yang dapat mempengaruhi self efficacy individu yaitu pencapaian prestasi, pengalaman orang lain, tingkat kesukaran tugas, status individu dalam lingkungan dan informasi mengenai kemampuan yang dimiliki. Oleh karena itu mahasiswa dengan self efficacy tinggi akan berusaha untuk dapat melaksanakan tugas, aktivitas atau tindakan tertentu dan terus berusaha apabila menemui hambatan dalam mencapai tujuan 
Dengan menggunakan penalaran di atas dapat diduga bahwa mahasiswa yang memiliki

Pengetahuan kewirausahaan dan self efficacy yang tinggi dan positif akan mempunyai kreativitas yang tinggi.Meskipun demikian ada beberapa indikator yang harus ditingkat dalam penelitian ini.

\section{Kesimpulan dan Saran}

Berdasarkan temuan hasil penelitian dan pengujian hipotesis serta pembahasan penelitian maka dapat ditarik kesimpulan sebagai berikut :

a. Pengetahuan kewirausahaan mempunyai hubungan positif dengan kreativitas mahasiswa, yaitu makin tinggi pengetahuan kewirausahaan maka makin tinggi kreativitas dan sebaliknya. Varibel pengetahuan kewirausahaan merupakan variabel penting untuk diperhatikan dalam usaha peningkatan kreativitas mahasiswa dalam kegiaatan berwirausaha. Disarankan agar meningkat indikator nilai-nilai kewirausahaan yang masih rendah yaitu keorsinilan. Sedangkan indikator pengetahuan berwirausaha yang masih rendah yaitu mengendalikan perusahaan

b. Self efficacy mempunyai hubungan positif dengan kreativitas mahasiswa, yaitu makin kuat Self efficacy maka makin tinggi kreatif mahasiswa dalam kegiatan berwirausaha, dan sebaliknya. Oleh sebab itu Self efficacy yang dimiliki mahasiswa merupakan variabel penting untuk diperhatikan dalam usaha peningkatan kreativitas. Dimensi keyakinan akan potensi diri indikator terendah adalah menjadi wirausaha yang berhasil, dimensi dimensi keyakinan kesuksesan yang terendah adalah kepercayaan dari mitra dan dimensi. Dimensi keyakinan keyakinan tetap survive yang paling rendah adalah keyakinan belajar wirausaha akan berkembang. Sedangkan dalam kreativitas pribadi kreatif minat terhadap aktivitas kreatif, dimensi proses kreatif yang harus ditingkatkan adalah kelancaran dalam berpikir, dimensi pendorong kreatif yang hatus ditingkatkan adalah sekolah dan dimensi produk kreatif yang harus diringkatkan adalah pengembangan produk.

c. Dari kedua varibel bebas yang diteliti masing-masing terdapat pengaruh positif antara pengetahuan kewirausahaan terhadap kreativitas, Self efficacy terhadap kreativitas serta secara bersama-sama pengetahuan kewirausahan dan Self efficacy terhadap kreativitas mahasiswa dalam kegiatan berwirausaha.

d. Disarankan bagi peneliti lain agar mengkaji kreativitas selain variabel pengetahuan kewirausahaan dan self efficacy.

\section{Daftar Pustaka}

Ajzen, I. (1991) The Theory of Planned Behavior. Organizational Behavior and Human Decision Process, 50, 179-211

Ajzen, I. (2008). Consumer Attitudes and Behavior. In C. P. Haugtvedt, P. M. Herr \& F. R. Cardes (Eds.), Handbook of Consumer Psychology (pp. 525- 548). New York: Lawrence Erlbaum Associates

Akbar, R.(2001). Kreativitas. Jakarta: PT. Grasindo (Gramedia Widiasarana Indonesia Alma, B (2002) Kewirausahaan Untuk Mahasiswa dan Umum. Bandung: Alfabeta. 
Alma, B.(2009) Kewirausahaan Untuk Mahasiswa dan Umum. Bandung: Alfabeta.

Amorós, J.E. and Bosma, N. (2014), "Global Entrepreneurship Monitor 2013 global report", available at: www.gemconsortium.org/docs/download/3106 (accessed February 13, 2015).

Andrikopoulos, A. (2005), "Using intellectual capital statements to determine value drivers and priorities for organizational change: a portfolio selection approach", Knowledge Management Research \& Practice, Vol. 3 No. 3, pp. 166-172.

Ayres, J. and Raveendranathan, G. (2015), "Lack of firm entry and the slow recovery of the US economy after the Great Recession", Mimeo

Bandura, A. (1997). Self Efficacy: the Exercise of Control. New York:Freeman

Baron, R. A. dan Byrne, D. (2004). Psikologi Sosial Jilid 1 (Edisi ke-10). Jakarta: Erlangga

Chuang, C. F., Shiu, S. C., \& Cheng, C. J. (2010). The Relation of College Students' Process of Study and Creativity: The Mediating Effect of Creative Self-Efficacy. World Academy of Science, Enginering and Technology, 960-963.

Edy Suandi Hamid (2015) (BPS provinsi Jawa Barat: http://pusdalisbang.jabarprov.go.id/pusdalisbang/beritastatistik-140.html) (diakses 15 Juli 2015)

Edy Suandi Hamid(2015) Pengangguran Banyak Bertitel Sarjana, tersedia dalam (https://news.okezone.com/read/2015/12/30/65/1277253/7-5-juta-pengangguranbanyak-bertitel-sarjana).( diakses 15 Juli 2015)

Gourio, F., Messer, T. and Siemer, M. (2014), "A missing generation of firms? Aggregate effects of the decline in new business formation", Mimeo.

Hasan, S.H. (1996) Pendidikan Ilmu Sosial, Dedikbud, Jakarta:Direktorat Jeneral Pendidikan Tinggi Proyek Pendidikan Tenaga Akademik.

Heny Dwi Astuti (2008) Hubungan Pengetahuan Keperpustakaan Dengan Kreativitas Guru Dalam Mengelola Perpustakaan SD di Kecamatan Banguntapan, Kabupaten Bantul, Yogyakarta, Program Studi Ilmu Perpustakaan, Jurusan Ilmu Perpustakaan dan Informasi Fakultas Adab. UIN Sunankalijaga Yogyakarta

Jamridafrijal.(2010) Faktor-Faktor Yang Mempengaruhi Kreativitas, tersedia dalam http://otoinfus.com/db/jamridafrizal-s-ag-s-s-mhum-kreativitas (25 Oktober 2011).

Kerlinger, F.N. (1990) Asas-asas Penelitian Behavioral, Penerjemah Landung R. Simatupang, Yogyakarta: Universitas Gajah Mada Press.

Kourilsky, M. L. dan W. B. Walstad, 1998. Entrepreneurship and Female Youth: Knowledge, Attitude, Gender Differences, and Educational Practices". Journal of Business Venturing 13 (1): 77-88.

McKinnon, W. D, (1970), Creativity: A Multi-faceted Phenomenon" dalam John D. Rolansky (Ed.) Creativity : A Discussion at the Nobel Conference, London: North Holland Publishing Company.

Mertayasa et al (2017) Hubungan Knowledge Management Terhadap Kreativitas Mahasiswa Jurusan Pendidikan Teknik Informatika Undiksha Singaraja Pendidikan Teknik Informatika Universitas Pendidikan Ganesha Singaraja, Bali, Kumpulan 
Artikel Mahasiswa Pendidikan Teknik Informatika (KARMAPATI) Volume 6, Nomor 1, 2017 ISSN 2252-9063

Munandar,U.1988, Kreativitas dan Makna Hidup" dalam S.C. Utami Munandar (Ed.), Kreativitas Sepanjang Masa, Jakarta: Pustaka Sinar Harapan

Semiawan,C.(1990). Pendekatan Keterampilan Proses. Bagaimanakah Mengaktifkan Siswa Dalam Belajar?. Jakarta: Grasindo.

Semiawan, C.(1996) Perspektif Pendidikan Anak Berbakat. Jakarta: Departemen

Pendidikan dan Kebudayaan, Direktorat Jenderal Pendidikan Tinggi, Proyek Pendidikan Tenaga Guru

Siemer, M. (2014), "Firm Entry and Employment Dynamics in The Great Recession", Working Paper No. 2014-56, FEDS

Semiawan, C.1996, Perspektif Pendidikan Anak Berbakat. Jakarta: Departemen

Pendidikan dan Kebudayaan, Direktorat Jenderal Pendidikan Tinggi, Proyek Pendidikan Tenaga Guru.

Sugiyono,(2014). Statistika Untuk Penelitian. Bandung: Alfabeta.

Subramaniam, M. and Youndt, M.A. (2005) The Influence of Intellectual Capital on the

Types of Innovative Capabilities. Academy of Management Journal, 48, 450-463.

Suherman (2008) Kewirausahaan Bussines Entrepreneur. Bandung: Alfabeta,

Suparman (1994), Pengelolaan Sumber Daya Manusia. Jakarta Bumi Aksara.

Sugiyono,2004,MetodologiPenelitian Administrasi, edisi kelima. Bandung: Alfabeta.

Suryana. 2006, Kewirausahaan. Pedoman Praktis, Kiat dan Proses Menuju Sukses: Jakarta: Salemba Empat.

Treffinger, D.L(1980) Encouriging Creative Learning for The Gifted and Talented, Ventura California

Wang, W. and Chang, C. (2005), "Intellectual Capital and Performance in Causal Models:

Evidence From the Information Technology Industry in Taiwan", Journal of Intellectual Capital, Vol. 6 No. 2, pp. 222-236.

Wagner III, J.A. \& Hollenbeck, J.R. (2010). Organizational Behavior: Securing Competitive Advantage. New York: Routledge 